\title{
Multidrug resistance in Shiga toxin-producing Escherichia coli (STEC) isolated from broiler chickens at slaughter
}

\section{Resistência a múltiplos antimicrobianos em Escherichia coli shigatoxigênica (STEC) isoladas de frangos de corte ao abate}

Rodrigo Pacheco Ornellas ${ }^{1}$; Hugo Peralva Lopes ${ }^{2}$; Daniela de Queiroz Baptista2; Thomas Salles Dias ${ }^{2 *}$; Arthur de Almeida Figueira ${ }^{1}$; Gisllany Alves Costa ${ }^{1}$; Leandro dos Santos Machado3; Nathalie Costa da Cunha4; Virginia Léo de Almeida

Pereira4; Dayse Lima da Costa Abreu ${ }^{4}$

\section{Highlights}

171 E. coli strains were isolated from chicken carcasses and cloaca.

$21.05 \%$ of the strains were characterized as STEC.

Association of $s t x 1$ with eae occurred in $66.67 \%$ of STEC strains.

Multidrug resistance pattern was observed in $42.22 \%$ of STEC strains.

\section{Abstract}

Broiler chickens and derived products are a key source of Shiga toxin-producing Escherichia coli (STEC) in humans. This pathotype is responsible for causing severe episodes of diarrhea, which can progress to systemic complications. A rapid and accurate diagnosis of the disease, and early treatment of the infection with antimicrobials, can prevent it worsening. However, multidrug-resistant strains have potentially negative implications for treatment success. In this context, the aim of the present study was to isolate and identify multidrug-resistant STEC strains from broiler chickens and carcasses. Of $171 \mathrm{E}$. coli strains, isolated by conventional microbiological techniques and submitted to Polymerase Chain Reaction (PCR), for detection of stx 1 and stx 2 genes, $21.05 \%$ (36/171) were STEC pathotype, and most of them $(66.67 \%-24 / 36)$ carried

1 Master Students in the Postgraduate Program in Veterinary Medicine, Veterinary Hygiene and Processing Technology of Animal Products, Universidade Federal Fluminense, UFF, Niteroi, RJ, Brazil. E-mail: ornellasmedvet@gmail.com; arthurfigueira@id.uff.br; gisllanyalves@id.uff.br

2 PhD Students in the Postgraduate Program in Veterinary Medicine, Veterinary Hygiene and Processing Technology of Animal Products, UFF, Niteroi, RJ, Brazil. E-mail: hugop_lopes@hotmail.com; daniqb@yahoo.com; thomassalles@ id.uff.br

${ }^{3}$ Postdoctoral Researcher in the Postgraduate Program in Veterinary Medicine, Veterinary Hygiene and Processing Technology of Animal Products, UFF, Niteroi, RJ, Brazil. E-mail: leomachadovet@gmail.com

${ }^{4}$ Prof. Dr. PhD, Department of Preventive Veterinary Medicine, UFF, Niteroi, RJ, Brazil. E-mail: nathaliecunha@id.uff.br; virginialeo@id.uff.br; dayseabreu@id.uff.br

* Author for correspondence

Received: May 28, 2021 - Approved: Aug. 13, 2021 
both stx 1 and eae genes. The multidrug resistance pattern was observed in 75\% (27/36) of STEC strains. The presence of STEC in broiler chickens and carcasses reinforces that these sources may act as reservoirs for this pathotype. Multidrug-resistant bacteria contaminating animal products represent a public health issue because of the possibility of spread of multidrug-resistant determinants in the food chain and a higher risk of failure in human treatment when antimicrobials are needed.

Key words: Broiler carcasses. Escherichia coli. Multidrug-resistance. STEC.

\section{Resumo}

Frangos de corte e seus produtos são importantes componentes na cadeia de transmissão de Escherichia coli do patotipo Shigatoxigênico (STEC) para humanos. Este patotipo é responsável por causar episódios de diarréia severos, que podem evoluir para complicações sistêmicas. O diagnóstico rápido e preciso da doença, e o tratamento com antimicrobianos ainda no início da infecção, podem evitar seu agravamento. Porém, cepas resistentes a múltiplos antimicrobianos podem ter implicações potencialmente negativas em relação ao sucesso do tratamento. Neste contexto, este estudo teve como objetivo isolar e identificar cepas STEC resistentes a múltiplos antimicrobianos em frangos de corte e carcaças. Das 171 cepas de E. coli isoladas pelo método bacteriológico convencional, e submetidas à Reação em Cadeia da Polimerase (PCR), para detecção dos genes stx1 e stx2, 21.05\% (36/171) pertenciam ao patotipo STEC, a maioria (66.67\% - 24/36) portando o gene stx1 associado ao gene eae. O perfil de multirresistência foi observado em $75 \%$ (27/36) das cepas STEC. A presença de cepas STEC no material estudado reforça o fato de que frangos vivos e carcaças devem ser considerados como reservatórios deste patotipo. A presença de cepas resistentes a múltiplos antimicrobianos, contaminando produtos de origem animal, representa um risco à Saúde Pública pela possibilidade de disseminação de determinantes de multirresistência e maior risco de insucesso no tratamento de indivíduos infectados.

Palavras-chave: Escherichia coli. Frango. Multirresistência. STEC.

\section{Introduction}

Escherichia coli is one of the major pathogens involved in foodborne outbreaks in Brazil (Brasil, 2019). Among E. coli pathotypes, Shiga toxin-producing Escherichia coli (STEC) is known to cause severe episodes of diarrhea that can progress to systemic complications (Pèrez-Cruz et al., 2017). Broiler chickens and derived products are reservoirs of this pathotype (Alonso, Lucchesi, Rodríguez, Parma, \& Padola, 2012; Doregiraee et al., 2016; Momtaz \& Jamshidi, 2011; Runa, Lijon, \& Rahman, 2018), playing an important role as source of transmission to humans.
Shiga toxin (STX) is the main virulence factor of STEC strains. There are two primary, distinct groups of STX, namely STX1 and STX2 (Hannah et al., 2009), which are encoded by the genes stx 1 and stx2 (Gobius, Higgs, \& Desmarchelier, 2003), that can occur simultaneously in the same strain (Fürst et al., 2000). STEC strains can synthesize intimin, a non-fimbrial adhesin that is encoded by the eae gene which is responsible for intestinal damage A/E (attaching and effacing) (Persson, Olsen, Ethelberg, \& Scheutz, 2007).The presence of the eae gene facilitates intestinal colonization by $E$. coli, and the interaction with $s t x$, especially $s t x 2$, can be responsible 
for increasing the development of hemolytic uremic syndrome (HUS) in humans (Ethelberg et al., 2004; Matussek, Jernberg, Einemo, Monecke, \& Ehricht, 2017).

A rapid and accurate diagnosis of infection caused by STEC is important for the success of the treatment since the use of antimicrobials at the beginning of the infection can decrease kidney damage and improve the prognosis of patients (GeerdesFenge et al., 2013). Molecular techniques, including polymerase chain reaction (PCR), provide rapid and sensitive detection of stx 1 and stx2 genes, and are an important tool for diagnosis (Hannah et al., 2009). Despite the rapid diagnosis and subsequent treatment of the diseases caused by STEC strains, resistance to multiple antimicrobials is often shown (Alikhani, Hashemi, Aslani, \& Farajnia, 2013; Ranjbar, Masoudimanesh, Dehkordi, \& Jonaidi-Jafari, 2017), which can make it difficult to successfully treat infections (Jafari et al., 2009).

Antimicrobial resistance is higher in environments where there is selection pressure for the constant use of these drugs (Blaak et al., 2015). In line with this, animal production has been implicated in increasing the frequency of antimicrobial resistance. However, even without the use of antimicrobials, the risk of strains being resistant to multiple antimicrobials is high, as resistance genes can be transferred between resistant and sensitive strains. To index this risk, the multiple antimicrobial resistance (MAR) index was developed (Krumperman, 1983). This index has been used for several bacterial genera and infers the risk of transmission of genetic determinants between bacterial strains, as well as the potential for resistance to several antimicrobials, from a given sample.

There is no relationship between pathogenicity and antimicrobial resistance in E. coli strains (El-rami, Rahal, Sleiman, \& Abdelnoor, 2012), although the association between pathogenic strains showing a multidrug resistance phenotype has been described (Barros et al., 2012). Thus, this study aimed to isolate and identify the STEC pathotype in broilers and carcasses and to assess the antimicrobial resistance patterns of the isolated strains.

\section{Materials and Methods}

\section{Sampling}

Cloacal content and broiler carcasses were collected from six different flocks slaughtered in six slaughterhouses which were inspected by the State Inspection Service in the state of Rio de Janeiro. At the reception area of each slaughterhouse, 40 broiler chickens were randomly selected to collect material from cloaca. The material was collected with sterile swabs, which were placed in groups of four swabs into tubes containing Cary Blair $\left(\mathrm{OXOID}^{\circledR}\right)$ medium, totaling 10 tubes per flock. Furthermore, ten carcasses from the same flock were randomly selected and removed from the overhead conveyor after dripping and were individually wrapped in sterile bags. In total, 60 samples of cloacal content and 60 carcasses were analyzed. The samples were packed in isothermal boxes with recyclable ice and processed within four hours of collection. 
Bacterial isolation and characterization of virulence genes

The swabs were washed in tubes containing $10 \mathrm{ml}$ of $1 \%$ peptone saline solution (PSS), and $400 \mathrm{ml}$ of $1 \%$ PSS was added to the bags containing the carcasses. The samples were manually shaken for $60 \mathrm{~s}$. All of the samples were incubated for $24 \mathrm{~h}$ at $37^{\circ} \mathrm{C}$. After incubation, 1\% PSS aliquots from both the swabs and broiler carcasses were streaked on MacConkey agar (KASVI) and were incubated for $24 \mathrm{~h}$ at $37^{\circ} \mathrm{C}$. Three fermenting colonies from each plate were selected and subjected to conventional biochemical identification using triple sugar iron (PRODIMOL), indole sulfide motility (KASVI), methyl red, Voges Proskauer and Citrate (MacFaddin, 2000).

The DNA of the E. colistrains, previously confirmed by biochemical tests, was extracted by the thermal method according to Andreatti, Gonçalves, Okamoto and Lima (2011) and was subsequently subjected to PCR to detect the stx 1 , st $x 2$, and eae genes using specific primers (Table 1).

\section{Table 1}

Primer oligonucleotides for detection of Shiga toxin-producing Escherichia coli by PCR, primers sequences, and amplicon length

\begin{tabular}{cccc} 
Genes & Primers $\left(5^{\prime}-3^{\prime}\right)$ & Amplicon Length & Reference \\
\multirow{2}{*}{ stx1 } & 5'-ATAAATCGCCATTCGTTGACTAC-3' & $180 \mathrm{pb}$ & \\
& 5'-AGAACGCCACTGAGATCATC -3' & & \\
stx2 & 5'-GGCACTGTCTGAAACTGCTCC-3' & $255 \mathrm{pb}$ & (Paton \& Paton, 1998) \\
& 5'-TCGCCAGTTATCTGACATTCTG-3' & & \\
eae & 5'-GACCCGGCACAAGCATAAGC-3' & \multirow{2}{*}{$384 \mathrm{pb}$} &
\end{tabular}

For the amplification reaction of the stx 1 and stx 2 genes, sterile ultra-pure water was added to $2 \mu \mathrm{L}$ of extracted DNA; $1 \mathrm{X}$ buffer; $1.5 \mathrm{mM} \mathrm{MgCl} ; 2.5 \mathrm{mM}$ dNTP; $0.4 \mathrm{mM}$ of each primer and $1 \mathrm{U}$ of Taq Polymerase (Ludwig Biotech), totaling the final volume of 25.00 $\mu \mathrm{L}$. For the eae gene amplification reaction, sterile ultra-pure water was added to $2 \mu \mathrm{L}$ of extracted DNA; 1 X buffer; $1.5 \mathrm{mM} \mathrm{MgCl}_{2} ; 0.2 \mathrm{mM}$ dNTP; $0.4 \mathrm{mM}$ of each primer and $1 \mathrm{U}$ of Taq Polymerase, totaling the final volume of 25.00 $\mu \mathrm{L}$ (Paton \& Paton, 1998). The amplification reactions were performed in a thermocycler (Programmable Thermal Controller-PTC-100) under the following conditions for all of the studied genes: initial denaturation at $94^{\circ} \mathrm{C}$ for 5 $\min , 30$ cycles of $94^{\circ} \mathrm{C}$ for $45 \mathrm{~s}$ for denaturation, initial extension at $59^{\circ} \mathrm{C}$ for 45 seconds, $72^{\circ}$ $\mathrm{C}$ for one minute and a final extension at $72^{\circ}$ $\mathrm{C}$ for $6 \mathrm{~min}$. The amplicons obtained in the PCR were separated on a $1.5 \%$ agarose gel, submerged in Tris-Borate-EDTA buffer (TBE), and subjected to an electrophoretic run at 94 $\mathrm{V}$ for $40 \mathrm{~min}$. After electrophoresis, the gel was stained with ethidium bromide, and the amplicons were visualized under ultraviolet light in a transilluminator. 


\section{Antimicrobial susceptibility testing}

The isolates were subjected to the disk diffusion test (Clinical and Laboratory Standards Institute, [CLSI], 2018) to characterize the resistance pattern to the following classes of antimicrobials: fluoroquinolone (Ciprofloxacin - 5 $4 \mathrm{~g}$ ); cephalosporin (Ceftazidime - 30 $\mathrm{gg}$ ); penicillin (amoxicillin with clavulanic acid - 20 /

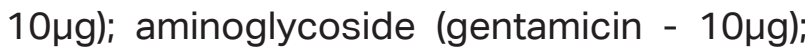

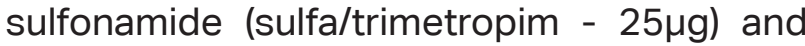
tetracycline (tetracycline - 30 $\mu$ g) (CEFAR ${ }^{\circledR}$ ).

\section{Determination of multidrug resistance}

Strains resistant to three or more different antimicrobials were considered multidrug resistant (MDR) (Magiorakos et al., 2011). The risk of dissemination of multidrug resistance determinants was calculated by the Multiple Antimicrobial Resistance (MAR) Index, according to Krumperman (1983), by the formula $a / b$, where "a" represents the number of antimicrobials for which isolate was resistant and " $b$ " the number of antimicrobials tested. When a given source had an MAR index above 0.2 , it was considered as likely to increase the risk of spreading multi-resistant strains (Krumperman, 1983; Osundiya, Oladele, \& Oduyebo, 2013).

\section{Statistical analysis}

The Bioestat 5.0 program was used to verify the association between the presence of STEC strains resistant to multiple antimicrobials and the source of the strains by Fisher's exact test, at a 5\% significance level.

\section{Results and Discussion}

A total of $171 \mathrm{E}$. coli strains were isolated, of which $21.05 \%$ (36/171) were characterized as STEC; $47.22 \%$ (17/36) were from cloacal content, and $52.78 \%(19 / 36)$ were from carcasses (Table 2). There was no statistically significant difference in the frequency of STEC from cloacal versus carcasses $(p>0,05)$. The stx 1 gene was the most frequently detected, occurring alone in $5.56 \%(2 / 36)$ of the isolates, associated with the stx2 gene in $19.44 \%(7 / 36)$, and with the eae gene in $66.67 \%$ (24/36). There was an association between the stx 1 and eae genes in both sources, occurring in $70.59 \%(12 / 17)$ of strains from cloaca and $63.16 \%(12 / 19)$ of the strains from carcasses (Table 2).

Among the STEC strains isolated from cloacal content, $70.59 \%$ (12/17) were resistant to sulfamethoxazole/trimethoprim and $88.24 \%(15 / 17)$ to tetracycline. Among the strains isolated from carcasses, $47.37 \%$ (9/19) were resistant to sulfamethoxazole/ trimethoprim and $52.63 \%(10 / 19)$ were resistant to tetracycline. Regarding nonSTEC strains from cloacal content, $58.73 \%$ (37/63) were resistant to sulfamethoxazole/ trimethoprim and $63.49 \% \quad(40 / 63)$ to tetracycline. Among non-STEC strains from carcasses, $44.44 \%$ (32/72) were resistant to sulfamethoxazole/trimethoprim and $54.17 \%$ $(39 / 72)$ to tetracycline. Table 3 presents the complete antimicrobial susceptibility patterns of the STEC and non-STEC strains. 
Table 2

Distribution and frequency of genes that characterize the strains of Escherichia coli as Shiga Toxigenic pathotype (STEC) isolated from cloaca and chicken carcasses

\begin{tabular}{ccccccccc|} 
Source & $s t \times 1$ & $s t \times 2$ & stx1+stx2 & stx1+eae & stx2+eae & STEC & NON STEC* & Total \\
Cloacal & 0 & 1 & 3 & 12 & 1 & 17 & 63 & 80 \\
& 2 & $(5,88 \%)$ & $(17,65 \%)$ & $(70,59 \%)$ & $(5,88 \%)$ & $(47,22 \%)$ & $(46,67 \%)$ & $(46,78 \%)$ \\
Carcass & 2 & 4 & 12 & & 19 & 72 & 91 \\
& $(10,53 \%)$ & $(5,26 \%)$ & $(21,05 \%)$ & $(63,16 \%)$ & 0 & $(52,78 \%)$ & $(53,33 \%)$ & $(53,22 \%)$ \\
\multirow{2}{*}{ Total } & 2 & 2 & 7 & 24 & 1 & 36 & 135 & 171 \\
& $(5,56 \%)$ & $(5,56 \%)$ & $(19,44 \%)$ & $(66,67 \%)$ & $(2,78 \%)$ & $(21,05 \%)$ & $(78,95 \%)$ & $(100 \%)$
\end{tabular}

*Non-STEC- E. coli strains without stx 1 and/or stx2 genes.

Multidrug resistance was detected in $42.22 \%(17 / 36)$ of STEC strains. Among the strains obtained from cloaca and carcass, 58.82\%(10/17) and 36.84\%(7/19) respectively, were multidrug-resistant. In non-STEC strains, $41.48 \%(56 / 135)$ were multidrug-resistant, of which $46.03 \%$ (29/63) were from cloaca and $37.50 \%(27 / 72)$ from carcasses.

According to the multiple antimicrobial resistance (MAR) index, 72.51\% (124/171) of the analyzed strains had an index greater than 0.2; among STEC strains, 75\% (27/36) had an MAR index greater than 0.2 (Table 4). In the strains from cloaca, the index varied from 0.14 to 0.71 and in the strains from carcasses, the variation was from 0.14 to 0.57 . Evaluation of the frequencies of multidrug resistance between STEC and non-STEC strains from cloaca ( $p=0,7242)$ and carcass ( $p=0,4921$ ) sources, indicate that there was no association between virulence and multidrug resistance.
In this study, we isolated and identified STEC strains with a multidrug resistance pattern from the cloacal contents and carcasses of broilers. Previous reports support our findings (Momtaz \& Jamshidi, 2011; Runa et al., 2018). Alonso et al. (2012), detected a higher frequency of STEC pathotypes in carcasses, when compared to the frequency in cloaca. According to these authors, processing, particularly gutting, can result in contamination of carcasses. In the current study, there was no difference in the frequency of isolation between cloacal and carcass sources, leading us to conclude that both sources have the same risk of carrying virulence genes that characterize the STEC pathotype. 
Table 3

Antimicrobial susceptibility profile of Escherichia coli strains producing (STEC) and not producing Shiga toxin (non-STEC) isolated from cloaca and chicken carcasses

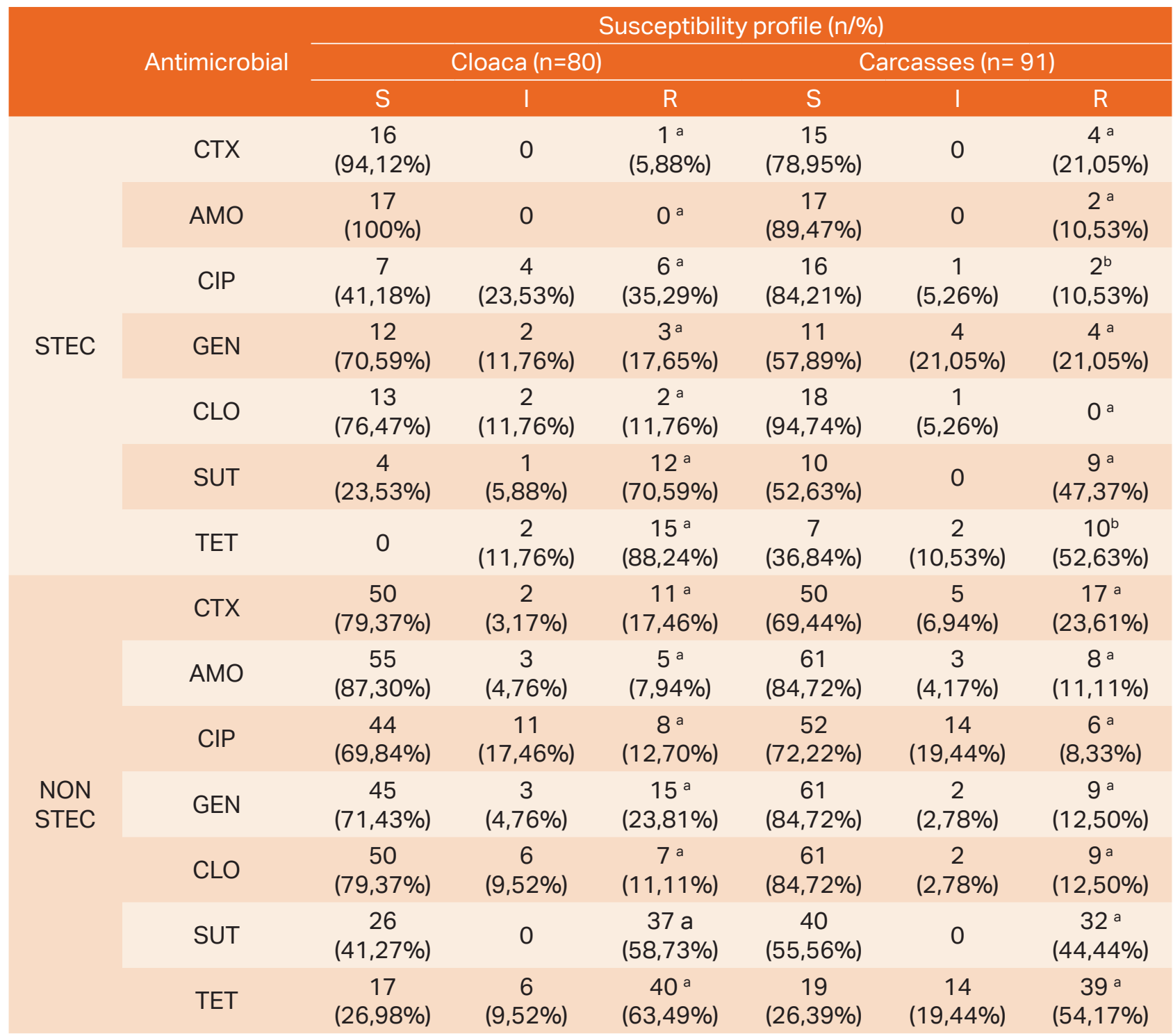

Different letters in the lines indicate statistical differences by Fisher's exact test between the different types of source (cloaca and carcass). CTX - Ceftazidime, AMO - Amoxicillin /Clavulanic Acid, CIP - Ciprofloxacin, GEN - Gentamicin, CLO - Chloramphenicol, SUT - Sulfamethoxazole/Trimethoprim, TET - Tetracycline. 
Table 4

Multiple Antimicrobial Resistance (MAR) Index in STEC and non-STEC strains isolated from cloaca and chicken carcasses

\begin{tabular}{ccccc}
\multirow{2}{*}{ Source } & Pathotype & \multicolumn{2}{c}{ MAR Index } & Total \\
\cline { 3 - 5 } & classification & $<0,2$ & $>0,2$ & 17 \\
Cloaca & STEC & $3(17,65 \%)$ & $14(82,35 \%)$ & 63 \\
& Non-STEC & $14(22,22 \%)$ & $49(77,78 \%)$ & 19 \\
\multirow{2}{*}{ Carcass } & STEC & $6(31,58 \%)$ & $13(68,42 \%)$ & 72 \\
\cline { 3 - 4 } Total & Non-STEC & $24(33,33 \%)$ & $48(66,67 \%)$ & $171(100 \%)$
\end{tabular}

MAR Index: Antimicrobial Multidrug-Resistance Index.

The isolated strains were considered STEC when carrying, either individually or in association, the stx 1 and stx2 genes which encode the production of STX, which is the main virulence factor of the STEC strains (Fürst et al., 2000; Gobius et al., 2003). In addition to STX, most strains carried the eae gene, which encodes intimin, a non-fimbrial adhesin (Persson et al., 2007) that facilitates intestinal adhesion by $E$. coli. Augmented adherence of the strain to the intestinal epithelium can facilitate systemic absorption of STX and can be responsible for increasing the development of hemolytic uremic syndrome (HUS) (Ethelberg et al., 2004; Matussek et al., 2017).

A high frequency of resistance to tetracycline in STEC strains was detected, as was the case in other reports (Momtaz \& Jamshidi, 2011). Tetracycline is widely used in animal husbandry because of its broad spectrum and low cost, which may contribute to an increase in antimicrobial resistance to this class (Granados-Chinchilla \& Rodríguez, 2017).
Multidrug resistance was present in isolates from both sources in this study, as well as in strains with MAR index values greater than 0.2. This indicates a significant risk of these strains carrying and disseminating genes of resistance to multiple antimicrobials to sensitive bacterial strains within the environment (Krumperman, 1983; Osundiya et al., 2013). Antimicrobial resistance has often been hypothesized to result from the use of antimicrobials in animal production. However, in addition to the impact of antimicrobial use on drug resistance, it has been suggested that the presence of antimicrobial-resistant strains may appear due to the transfer of resistance genes between resistant and sensitive strains (Verraes et al., 2013).

The treatment of human infections caused by STEC strains, when started early, can decrease kidney damage and improve the patient's prognosis (Geerdes-Fenge et al., 2013). However, treatment success can be impaired in infections caused by multidrugresistant strains (Jafari et al., 2009). 
Chickens, and raw or undercooked chicken meat, may represent a reservoir of antimicrobial-resistant genes that are transferable by mobile genetic elements. These genes can be disseminated to other species of bacteria, including those responsible for infections in humans, such as those isolated and reported in this study. These strains can emerge from breeding and processing environments. In this context, good practices in animal production, in addition to correct processing practices, must be adopted to minimize the presence of foodborne pathogens present in the final product.

\section{Conclusions}

The results presented in this study support the hypothesis that live broilers and carcasses are reservoirs of STEC and may act as a source of this pathogen to humans, either by direct contact with carrier birds or by handling and ingestion of contaminated derived products. The presence of this pathotype in cloacal material and carcasses was confirmed by the detection of the specific virulence genes st $x 1$ and st $x 2$, in addition to the association of these genes with the eae genes, which increase the severity of infections. The multidrug resistance detected in STEC strains may increase the risk of treatment failure in cases of infections caused by this pathotype.

\section{Acknowledgments}

This study was financed in part by the Coordenação de Aperfeiçoamento de Pessoal de Nível Superior - Brasil (CAPES) - Finance Code 001.

\section{References}

Alikhani, M. Y., Hashemi, S. H., Aslani, M. M., \& Farajnia, S. (2013). Prevalence and antibiotic resistance patterns of diarrheagenic Escherichia coli isolated from adolescents and adults in Hamedan, Western Iran. Iranian Journal of Microbiology, 5(1), 42-47. Retrieved from https://www.ncbi.nlm.nih.gov/pmc/ articles/PMC3577554/

Alonso, M. Z., Lucchesi, P. M. A., Rodríguez, E. M., Parma, A. E., \& Padola, N. L. (2012). Enteropathogenic ( EPEC ) and shigatoxigenic Escherichia coli (STEC) in broiler chickens and derived products at different retail stores. Food Control, 23(2), 351-355. doi: 10.1016/j. foodcont.2011.07.030

Andreatti, R. L., Fo., Gonçalves, G. A. M., Okamoto, A. S., \& Lima, E. T. de. (2011). Comparação de métodos para extração de DNA na reação em cadeia da polimerase para detecção de Salmonella enterica sorovar Enteritidis em produtos avícolas. Ciência Animal Brasileira, 12(1), 115-119. doi: 10.5216/cab.v12i1.3774

Barros, M. R., Silveira, W. D. da, Araújo, J. M. de, Costa, E. P., Oliveira, A. A. da F., Santos, A. P. da S. F.,... Mota, R. A. (2012). Resistência antimicrobiana e perfil plasmidial de Escherichia coli isolada de frangos de corte e poedeiras comerciais no Estado de Pernambuco. Pesquisa Veterinária Brasileira, 32(5), 405-410. doi: 10.1590/ S0100-736X2012000500008

Blaak, H., Hoek, A. H. A. M. Van, Hamidjaja, R. A., Plaats, R. Q. J. Van Der, Heer, L. K., Maria, A.,... Schets, F. M. (2015). Distribution, numbers, and diversity of 
ESBL- producing $E$. coli in the poultry farm environment. Plos One, 8(13), 1-23. doi: 10.1371/journal.pone.0135402

Brasil, M. da S. (2019). Surtos de doenças transmitidas por alimentos no Brasil. Brasília:Secretaria de Vigilância em Saúde. Retrieved from https://portalarquivos2. saude.gov.br/images/pdf/2019/fevereiro /15/Apresenta----o-Surtos-DTA--Fevereiro-2019.pdf

Clinical and Laboratory Standards Institute (2018). Performance standards for antimicrobial susceptibility testing, M100 performance standards for antimicrobial susceptibility testing (28nd ed.). Wayne: CLSI.

Doregiraee, F., Alebouyeh, M., Fasaei, B. N., Charkhkar, S., Tajedin, E., \&Zali, M. R. (2016). Isolation of atypical enteropathogenic and shiga toxin encoding Escherichia coli strains from poultry in Tehran, Iran. Gastroenterology and Hepatology from Bed to Bench, 9(1), 53-57. doi: 10.22037/ ghfbb.v1i9.866

El-Rami, F. E., Rahal, E. A., Sleiman, F. T., \& Abdelnoor, A. M. (2012). Identification of virulence genes among antibacterialresistant Escherichia coli isolated from poultry. Advanced Studies in Biology, 4(8), 385-396. Retrived from http://www.mhikari.com/asb/asb2012/asb5-8-2012/ abdelnoorASB5-8-2012.pdf

Ethelberg, S., Olsen, K. E. P., Scheutz, F., Jensen, C., Schiellerup, P., Engberg, J.,... Mølbak, K. (2004). Virulence factors for virulence factors for hemolytic uremic syndrome, Denmark. Emerging Infectious Diseases, 10(5), 843-847. doi: 10.3201/ eid1005.030576
Fürst, S., Scheef, J., Bielaszewska, M.,

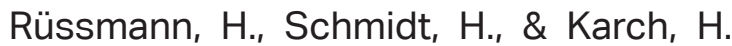
(2000). Identification and characterisation of Escherichia coli strains of 0157 and non-0157 serogroups containing three distinct Shiga toxin genes. Journal of Medical Microbiology, 49(4), 383-386. doi: 10.1099/0022-1317-49-4-383

Geerdes-Fenge, H. F., Lobermann, M., Nrnberg, M., Fritzsche, C., Koball, S., Henschel, J.,... Reisinger, E. C. (2013). Ciprofloxacin reduces the risk of hemolytic uremic syndrome in patients with Escherichia coli 0104 : H4-associated diarrhea. Infection, 2013(41), 669-673. doi: 10.1007/s15010012-0387-6

Gobius, K. S., Higgs, G. M., \& Desmarchelier, P. M. (2003). Presence of activatable shiga toxin genotype (stx $2 d$ ) in shiga toxigenic Escherichia coli from livestock sources. Journal of Clinical Microbiology, 41(8), 3777-3783. doi: 10.1128/JCM.41.8.3777

Granados-Chinchilla, F., \& Rodríguez, C. (2017). Tetracyclines in food and feedingstuffs: from regulation to analytical methods, bacterial resistance, and environmental and health implications. Journal of Analytical Methods in Chemistry, 2017(1), 1-24. doi: 10.1155/2017/1315497

Hannah, G., Bopp, C., Strockbine, N., Atkinson, R., Baselski, V., Body, B.,... Gerner-Smidt, P. (2009). Recommendations for diagnosis of shiga toxin-producing Escherichia coli infections by clinical laboratories. Centers for Disease Control and Prevention, 58(RR12);1-14. Retrieved from https:// www. cdc.gov/mmwr/preview/mmwrhtml/ rr5812a1.htm 
Jafari, F., Hamidian, M., Rezadehbashi, M., Doyle, M., Salmanzadeh-ahrabi, S., Derakhshan, F., \& Zali, M. R. (2009). Prevalence and antimicrobial resistance of diarrheagenic Escherichia coli and Shigella species associated with acute diarrhea in Tehran, Iran. Canadian Journal of Infectious Diseases and Medical Microbiology, 20(3), e56-e62. doi: 10.1155/2009/341275

Krumperman, P. H. (1983). Multiple antibiotic resistance indexing of Escherichia coli to identify high-risk sources of faecal contamination of water. Environmental Science and Pollution Research, 22(14), 10969-10980. doi: 10.1007/s11356-0143887-3

MacFaddin, J. F. (2000). Biochemical tests for identification of medical bacteria (3nd ed.). Baltimore (Md.): Williams and Wilkins.

Magiorakos, A., Srinivasan, A., Carey, R. B., Carmeli, Y., Falagas, M. E., Giske, C. G.,... Hindler, J. F. (2011). bacteria: an international expert proposal for interim standard definitions for acquired resistance. Clinical Microbiology and Infection, 18(3), 268-281. doi: 10.1111/ j.1469-0691.2011.03570.x

Matussek, A., Jernberg, C., Einemo, I., Monecke, S., \& Ehricht, R. (2017). Genetic makeup of Shiga toxin-producing Escherichia coli in relation to clinical symptoms and duration of shedding: a microarray analysis of isolates from Swedish children. European Journal of Clinical Microbiology and Infectious Diseases, 2017(36), 14331441. doi: 10.1007/s10096-017-2950-7

Momtaz, H., \& Jamshidi, A. (2011). Shiga toxin-producing Escherichia coli isolated from chicken meat in Iran: serogroups, virulence factors, and antimicrobial resistance properties. Poultry Science, 92(5), 1305-1313. doi: 10.3382/ps.201202542

Osundiya, O., Oladele, R., \& Oduyebo, O. (2013). Multipleantibiotic resistance (MAR) indices of Pseudomonas and Klebsiella species isolates in Lagos University Teaching Hospital. African Journal of Clinical and Experimental Microbiology, 14(3), 164168. doi: 10.4314/ajcem.v14i3.8

Paton, A. W., \& Paton, J. C. (1998). Detection and characterization of Shiga toxigenic Escherichia coli by using multiplex PCR assays for stx1, stx2, eaeA, enterohemorrhagic E. coli hlyA, rfb0111, and rfb0157. Journal of Clinical Microbiology, 36(2), 598-602. doi: 10.11 28/JCM.36.2.598-602.1998

Pèrez-Cruz, F. G., Villa-Díaz, P., PintadoDelgado, M. C., Fernández Rodriguez, M. L., Blasco-Martínez, A., \& Pérez-Fernández, M. (2017). Hemolytic uremic syndrome in adults: a case report Fabiel. World Journal of Critical Care Medicine, 3141(2), 135139. doi: 10.5492/wjccm.v6.i2.135

Persson, S., Olsen, K. E. P., Ethelberg, S., \& Scheutz, F. (2007). Subtyping method for Escherichia coli Shiga toxin (Verocytotoxin) 2 variants and correlations to clinical manifestations. Journal of Clinical Microbiology, 45(6), 2020-2024. doi: 10.1128/JCM.02591-06

Ranjbar, R., Masoudimanesh, M., Dehkordi, F. S., \& Jonaidi-Jafari, N. (2017). Shiga (Vero) - toxin producing Escherichia coli isolated from the hospital foods; virulence factors, o-serogroups and antimicrobial resistance properties. Antimicrobial Resistance \& Infection Control, 2017(6:4), 1-11. doi: 10.1186/s13756-016-0163-y 
Runa, J. A., Lijon, M. B., \& Rahman, M. A. (2018). Detection of multidrug resistant and shiga toxin producing Escherichia coli (STEC ) from apparently healthy broilers in Jessore, Bangladesh. Frontiers in Environmental Microbiology, 4(1), 16-21. doi: 10.11648/j.fem.20180401.13
Verraes, C., Van Boxstael, S., Van Meervenne, E., Van Coillie, E., Butaye, P., Catry, B.,... Herman, L. (2013). Antimicrobial resistance in the food chain: a review. International Journal of Environmental Research and Public Health, 10(7), 26432669. doi: 10.3390/ijerph10072643 